\title{
Examine Relationship of Soft Skills, Hard Skills, Innovation and Performance: the Mediation Effect of Organizational Learning
}

\author{
Arman Syah Putra ${ }^{1}$, Dewiana Novitasari ${ }^{2}$, Masduki Asbari $^{3 *}$, Agus Purwanto ${ }^{4}$, \\ Joni Iskandar ${ }^{5}$, Dhaniel Hutagalung ${ }^{6}$, Suroso $^{7}$, Yoyok Cahyono ${ }^{8}$ \\ 1,3,5,7 STMIK Insan Pembangunan, Tangerang, Indonesia \\ ${ }^{2,6}$ Sekolah Tinggi Ilmu Ekonomi Insan Pembangunan, Tangerang, Indonesia \\ ${ }^{3,4}$ Pelita Harapan University, Tangerang, Indonesia \\ ${ }^{8}$ Universitas Pramita Indonesia, Tangerang, Indonesia
}

\begin{abstract}
The purpose of this research was to measure the effect of hard skills and soft skills towards teachers' innovation capability which was mediated by an organizational learning and to measure the effect of teachers' innovation capability towards their performance. Data collection was done by simple random sampling to 251 population of the teachers in five private senior high schools di Tangerang. The returned and valid questionnaire results were 211 samples. SEM method with SmartPLS 3.0 software is used for data processing. Hard skills and soft skills are concluded as a result of research that has a positive and significant effect on the capability of teachers' innovation, both directly and indirectly through mediation of the organizational learning. As well as the capability of teachers' innovation has a positive and significant effect on their performance. A model for building innovation capability and teacher performance among teachers in Tangerang through enhancing hard and soft skills with organizational learning as a mediator was proposed as new research. To improve teacher readiness in facing the era of education 4.0 this study was pave.
\end{abstract}

Keywords - Hard skills, organizational learning, performance, soft skills, teachers' innovation capability

\section{INTRODUCTION}

Dramatic changes that come from industrial revolution 4.0 become a new challenge for education. This industrial revolution requires qualified, agile, adaptive and responsive human resources against a rapid change. The world of education is facing rapid economic, social, political and technological change. Therefore, schools must be flexible to be able to adapt of the changing situations and contexts. An environment that continues to grow positive and conducive is needed for shool and other educational institutions to compete in global human resources. Therefore, synergy between teachers and the work environment is needed by schools to make continuous improvements in innovation and performance. The point is that innovation and flexibility in the era of economic knowledge are needed by the community as energy to survive competition. Increasing knowledge resources is the strategic development of educational institutions in the future, especially teachers, which provide space for innovation and growth.

To ensure that educational institutions, teachers need to be directed and involved in pumping school performance so that schools can be competitive and adaptive. Teachers must be powered and empowered. As a result, schools must manifest into real organizational learning. Organizational learning that empowers teachers as one of the main elements of school transformation, as well as teachers as instruments of civilization. The form of schools as the organizational learning is very important for educational institutions that operate in the environments with rapid and unexpected changes. So that, absolute condition for the creation of human resources is the speed of response to change, becomes an requirement to, students who are competitive and win global human resources competition.

Intellectual capital consisting of the knowledge of each teacher and school will become a new icon that illustrates the economic value of a school. This is the new paradigm adapted from industrial revolution 4.0. Major future investment contribution no longer depend on traditional productive assets such as buildings, constructions, land and other tangible assets. Teacher knowledge is an intangible asset that is a productive and sustainable asset in the future. This research seeks to understand and explain the effect of teachers' hard skills 
and soft skills on their 'teachers' innovation capability', then, to measure the effect of the organizational learning mediation on the relationship between hard skills, soft skills and teachers' innovation in Indonesia.

\section{LITERATURE REVIEW}

\section{Hard Skills}

Hard skills are one type of knowledge that is easily documented and formed (Choi \& Lee, 2003; Sousa \& Rocha, 2019; Borrego et al, 2019; Wokcik et al, 2019; Cifariello, Ferragina \& Ponza, 2019; Che et al, 2018; Tang et al, 2016; Bashir \& Farooq, 2019; Attia \& Salama, 2018), easily articulated (Haamann \& Basten, 2018) and usually constitute knowledge that inherent in schools (Afsar, Masood \& Umrani, 2019). In addition, hard skills can be created, written and transferred between school activity units (Lombardi, 2019). The transfer of hard skills among teachers is easier to be encouraged by a conducive school mechanisms and culture.

Hard skills can be described in general and are also based on the specific context in which these skills are used. Rainsbury et al. (2002) defines hard skills as skills that related to technical aspects for carrying out several tasks at work. Therefore, hard skills are basically cognitive and are affected by intellectual quotient (IQ) (Muhammad et al., 2019; Kenayathulla, Ahmad \& Idris, 2019; Tsotsotso et al., 2017; Fan, Wei \& Zhang, 2017). Contextually, some researchers use the concept of hard skills in particular the state of management. Azim et al. (2010) generally refers to hard skills in the context of project management as processes, procedures, tools, and techniques (Gale et al, 2017; Laker \& Powell, 2011)

Behavior and skills that can be seen is a picture of hard skills (explicit). Hard skills are the main skills that produce something that can be seen and directly. Technical or practical tests can assess hard skills. Intelligence thinking that has indicators for calculating, analyzing, designing, broad insights and knowledge, modeling and critical are elements of hard skills. Mastery of science, technology and technical skills related to the part of knowledge related the hard skills. A teacher must have expertise in opening lessons, managing classes, designing group discussions, arranging rooms, and writing well (Muqowim, 2012). Hard skills are relatively easy skills to measure. Widoyoko distinguishes between two hard skills, namely their academic and vocational skills. Academic skills are the ability to master various concepts in the field of research, such as skills to define, count, explain, describe, classify, identify, describe, predict, analyze, compare, differentiate, and draw conclusions from various concepts, data and facts related to the subject (Widoyoko, 2009).

\section{Soft Skills}

Two types of knowledge classification that is: soft skills and hard skills (Polanyi, 1966). Knowledge that is still in the human mind and is very personal is definition of soft skills (Chen et al, 2018; Holford, 2018; Khoshorour \& Gilaninia, 2018; Zebal, Ferdous \& Chambers, 2019; Agyemang \& Boateng, 2019; PerezFuillerat et al, 2018), it is difficult to be formulated and divided naturally (Deranek, McLeod \& Schmidt, 2017; Wang \& Liu, 2019; Asher \& Popper, 2019) personal interaction is needed by transformation (Lee, 2019). A person's actions and experiences, including idealism, values, and emotions are the roots of soft skills (Boske \& Osanloo, 2015; Kawamura, 2016; Hartley, 2018).

Based on its understanding, personal knowledge or in other words knowledge obtained from individuals or personal are categorize soft skills (Nonaka \& Toyama, 2015; Munoz et al, 2015; Stewart et al, 2017; Razmerita et al, 2016; Jaleel \& Verghis, 2015; Wang et al., 2016; Serna et al., 2017; Jou et al., 2016; Rothberg \& Erickson, 2017). Each teacher gets a different experience based on situations and conditions that cannot be predicted. Soft skills are not easily articulated and converted into hard skills (Mohajan, 2016; Prasarnphanich et al, 2016; Addis, 2016; Cairo Battistutti, 2017; Zang et al, 2015; Spraggon \& Bodolica, 2017). However, the process of knowledge spiral or SECI Model can empower by soft skills (Li, Liu \& Zhou, 2018; Nonaka \& Hirose, 2018; Chatterjee et al, 2018; Sasaki, 2017; Lievre \& Tang, 2015; Stanica \& Peydro, 2016 ; Norwich et al., 2016; Hodgins \& Dadich, 2017; Balde et al., 2018; Okuyama, 2017; Huang et al., 2016).

Teacher soft skills must be used to encourage them to share knowledge and keep learning for each school educational institution. School educational institutions like this will become more creative, innovative and lead in the era of education 4.0. Management and use of tacit knowledge that is outside the awareness stored in the subconscious mind of each teacher with an embedding and sharing approach can be facilitated by schools (Ma et al, 2018; Ferreira et al, 2018; Borges et al, 2019; Ferraris et al, 2018; Guo et al, 2018; Tsai \& Hsu, 2019; Swierczek, 2019; Cantwell \& Zaman, 2018). 


\section{Organizational Learning}

Crises will more resilient to good organizational learning (Starbuck, 2017). Organizational learning present as important elements of the dimensions such as desire, discipline, decision making, and alignment (Wetzel \& Tint, 2019; Urban \& Gaffurini, 2018). An important performance indicator for evaluating overall organizational performance is organizational learning (Qi \& Chau, 2018) which is able to help build the knowledge resources needed to maintain school growth and continuity. The distinguishing factor between one school and another is the ability to access knowledge. The strong knowledge base possessed by each individual from a school education institution is very significantly related to the success of school education institution's strategy.

\section{Teachers' Innovation Capability}

Teacher innovation skills are needed in the industrial era 4.0 as a competitive advantage in schools (Malik, 2019; Muscio \& Ciffolili, 2019; Durana et al, 2019; Lund \& Karlsen, 2019; Haseeb et al, 2019; Jakhar et al, 2018; Hamada, 2019; 2019), competitive strategy (Culot, Orzes \& Sartor, 2019), the key to face industry era 4.0 (Stachova et al, 2019) part of the quality of 21st century management (Gunasekaran, Sabramanian \& Ngai, 2019), has many advantages business (Zambon et al., 2019; Parida, Sjodin \& Reim, 2019). One of the most important internal resources that can produce superior school educational institution performance recognize as an innovation capability (Zouaghi et al, 2018; Santoro et al, 2017; Castela et al, 2018; Ruiz-Torres et al, 2018; Huesig \& Endres , 2019). Innovation is an important aspect of quality education (Klaeijsen, Vermeulen, \& Martens, 2017).

\section{Performance}

According to Campbell (1990), a series of individual actions and behaviors that are relevant to the organization's goals are a reference to individual performance. "The extent to which work is done well" is one of the simplest definitions of individual performance (Campbell et al., 1993). Not only to ensure better school management, but also to facilitate services to the development of science required employee performance appraisal. Thus, good individual performance means the teacher has completed work related responsibilities to the satisfactory extent or to the extent expected by school management.

\section{The effect of Hard skills and Soft Skills towards Teachers' Innovation Capability}

Increasingly fierce competition, sustainability remains a concern and important issues mark the current industry 4.0 era. Business sustainability are drived by teachers' innovation capability. The culture of knowledge that exists in organizations influences a performance. Knowledge consists of tacit and hard skills. Teacher innovation abilities that are influenced by leadership are discussed by many researchers (Samsir, 2018; Schuckert et al, 2018; Villaluz \& Hechanova, 2019), employee involvement climate (Naqshbandi, Tabche \& Choudhary, 2019) knowledge sharing (Kim \& Shim, 2018) knowledge search (Wang, Chen \& Chang, 2019) collaborative culture (Yang, Nguyen \& Le, 2018) and knowledge process (Imran et al, 2018). This research will evaluate the effect of hard and soft skills regarding teacher innovation competencies in school educational institutions to deal with the industrial revolution 4.0. The positive and significant effect of hard and soft skills on teachers' innovation capability have been proven by previous researchers (Ganguly et al, 2019; Aulawi, 2018; Rumanti et al, 2018 \& 2019; Torres \& Liang, 2016; Li et al, 2019). More specifically, soft skills have a positive and significant effect on the ability of teacher innovation this was concluded by many researchers (Perez-Luno et al, 2018). All of them are within the scope of business organizations. However, there are researchers who state that formal \& informal learning affect teachers' innovation capability of teachers in schools (Lecat, Beausaert, \& Raemdonck, 2018). Based on the above literature, the following hypotheses are arranged:

$\mathrm{H}^{1}$ : Hard skills directly effect towards teachers' innovation capability

$\mathrm{H}^{2}$ : Soft skills directly effect towards teachers' innovation capability

\section{The effect of Hard skills and Soft Skills towards Organizational Learning}

One strategy for organizations to study the dynamics of the business environment is in learning organization (Senge, 1990; Zhu et al., 2018; Kasim et al., 2018; Darwish et al., 2018). Learning routines will 
produce a collection of knowledgeable individuals, both hard and soft skills was managed by schools (Hussain et al, 2018). The organizational learning is affected by collaborative culture and knowledge sharing is concluded by some researchers (Nugroho, 2018). Very significant predictors for the development of the organizational learning find the soft skills (Muthuveloo, Shanmugam \& Teoh, 2017). Based on the above literature, the hypotheses to be examined are as follows:

$\mathrm{H}^{3}$ : Hard skills directly effect towards organizational learning

$\mathrm{H}^{4}$ : Soft skills directly effect towards organizational learning

\section{The effect of the Organizational Learning towards Teachers' Innovation Capability}

Organizational learning will trigger and spur teacher innovation abilities and organizational performance was conditioned by knowledge creation (Asbari, Purwanto \& Santoso, 2019; Vijande \& Sanchez, 2017; Lin \& Lee, 2017). Learning culture that adds value will be sustainable when based on school innovation. All teachers interact with each other so that their current knowledge and new knowledge acquired can be effectively transferred, exchanged and combined into school intelligence and knowledge of the school was used as a learning culture (Lin \& Lee, 2017; Lee et al, 2016; Chang \& Lin , 2015). An organizational environment that provides excitement at work is an important factor in creating teachers' innovation capability of the organizational members (Bani-Melhem, Zeffane \& Albaity, 2018). Furthermore, based on the above literature, the hypotheses to be examined are as follows:

$\mathrm{H}^{5}$ : Organizational learning directly effect towards teachers' innovation capability

\section{The effect of Teachers' Innovation Capability towards Teachers' Performance}

Organizations need to increase their flexibility, responsiveness, and efficiency, and innovation to respond challenges that faced in local and global competition (Asbari et al, 2019; Asbari et al., 2020; Purwanto et al., 2020). This is due to the rapidly increasing need for innovative product and service capabilities as well as internal processes and behavior of all members on the organization. In addressing this issue, previous researches emerged that have explored shifting from an efficiency view to innovation. The need for more knowledge about how individuals can be coordinated is to improve innovation and performance at the organizational level (Sopa et al, 2020). In addition, Asbari et al (2020) argues that internal processes should create innovations which contribute to improve performance. While Prameswari et al (2020) show that employee innovation indirectly affects the value of the organization through its effect on market and financial position. Nevertheless, according to Sopa et al. (2020) mention that innovation is very important for improving teachers' performance and they show that schools which focus on teachers' innovation will be more productive and competitive in the global education market. Therefore, we hypothesize:

\section{$\mathrm{H}^{6}$ : Teachers' innovation capability directly effect towards teachers' performance}

\section{The Mediation Effect of the Organizational Learning towards the relationship of Hard Skills, Soft Skills and Teachers' Innovation Capability}

Honeycutt (2000) explains that knowledge management is a discipline that treats intellectual capital from managed assets. Because, the concept of knowledge management basically develops from the fact that in the present and future, the main assets of an organization to be able to compete are intellectual or knowledge assets, not physical assets. In general, knowledge management carried out by the organizational learning is a technique or way to manage knowledge in organizations to create value and increase competitive advantage. The organizational learning as a mediation variable plays a role between hard skills, soft skills and the organizational innovation. In addition, this process has been considered as a system where knowledge and skills are input, the organizational learning is the main process, and the organizational innovation is an important output (Nouri \& Ghorbani, 2017; Chang, Liao \& Wu, 2017).

Furthermore, based on the above literature, the hypotheses to be examined are as follows:

$\mathrm{H}^{7}$ : Hard skills indirectly effect towards teachers' innovation capability through the organizational learning mediation

$\mathrm{H}^{8}$ : Soft skills indirectly effect towards teachers' innovation capability through the organizational learning mediation 


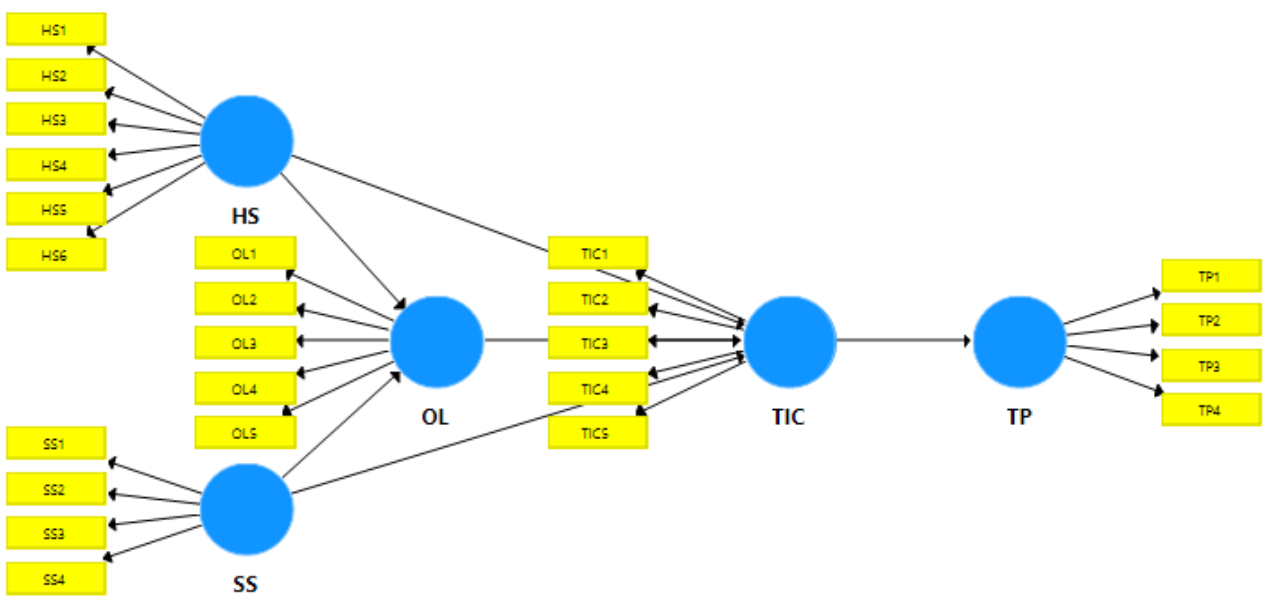

Figure 1. Research Model

\section{III.METHOD}

Definition of Operational Variables dan Indicators

In this research is quantitative method was used as the method. Data was collected by distributing questionnaires to all teachers of school education institutions. To measure hard skills was used the instrument adapted from Hendarman \& Cantner (2017) using six items. Soft skills were also adapted from Hendarman \& Cantner (2017) using four items. Instruments adapted from Jiménez-Jiménez and Sanz-Valle (2011) measure the organizational learning using five items. Lee \& Choi (2003) adapted teachers' innovation capability using five items. Teachers' performance was adapted from Grace et al (2016) using four items. For questions / statements about the respondent's identity in the form of a semi-open questionnaire designed by a closed questionnaire. Five answer options give each closed question / statement item given, namely: strongly agree (SS) score 5, agree (S) score 4, less agree (KS) score 3, disagree (TS) score 2, and strongly disagree (STS ) score 1. PLS and SmartPLS software version 3.0 are used as a method for processing data.

\section{1) Population and Sample}

Data collection was done by simple random sampling to 251 population of the teachers in five private senior high schools di Tangerang. The returned and valid questionnaire results were 211 samples (88.05 percent).

\section{IV.RESULTS AND DISCUSSION}

\section{Description of Sample}

Table 1. Information descriptive of the sample

\begin{tabular}{llcc}
\hline \multicolumn{1}{c}{ Criteria } & & Total & $\%$ \\
\hline Age (per October 2019) & $<30$ years & 45 & $20.41 \%$ \\
& 30 - 40 years & 103 & $46.60 \%$ \\
& $>40$ years & 73 & $32.99 \%$ \\
\hline Teachers' Status & Public (ASN) & 69 & $31.07 \%$ \\
& Private (Swasta) & 152 & $68.93 \%$ \\
\hline Service period as teacher & $<5$ years & 70 & $31.66 \%$ \\
& $5-10$ years & 107 & $48.52 \%$ \\
& $>10$ years & 44 & $19.82 \%$ \\
\hline Highest education & $<\quad$ S1(bachelor & 18 & \\
& degree) & & \\
& $\geq \quad$ S1 (bachelor & 203 & $92.99 \%$ \\
& degree) & & \\
\hline
\end{tabular}




\section{Validity and Reability Test Result of Research Indicator}

Convergent validity, discriminant validity and composite reliability testing are the measurement models used in the testing phase. To test the research hypothesis if all the indicators in the PLS model have met the requirements of convergent validity, discriminant validity and reliability testing can use the results of the PLS analysis.

\section{Convergent Validity Test}

To see the loading factor value of each indicator, do a convergent validity test. For most references, latent constructs are considered to have sufficiently strong validation explained through a factor weighting of 0.5 or more (Chin, 1998; Hair et al, 2010; Ghozali, 2014). AVE requirements for each construct>0.5 are accepted as the minimum loading factor size in this study (Ghozali, 2014).

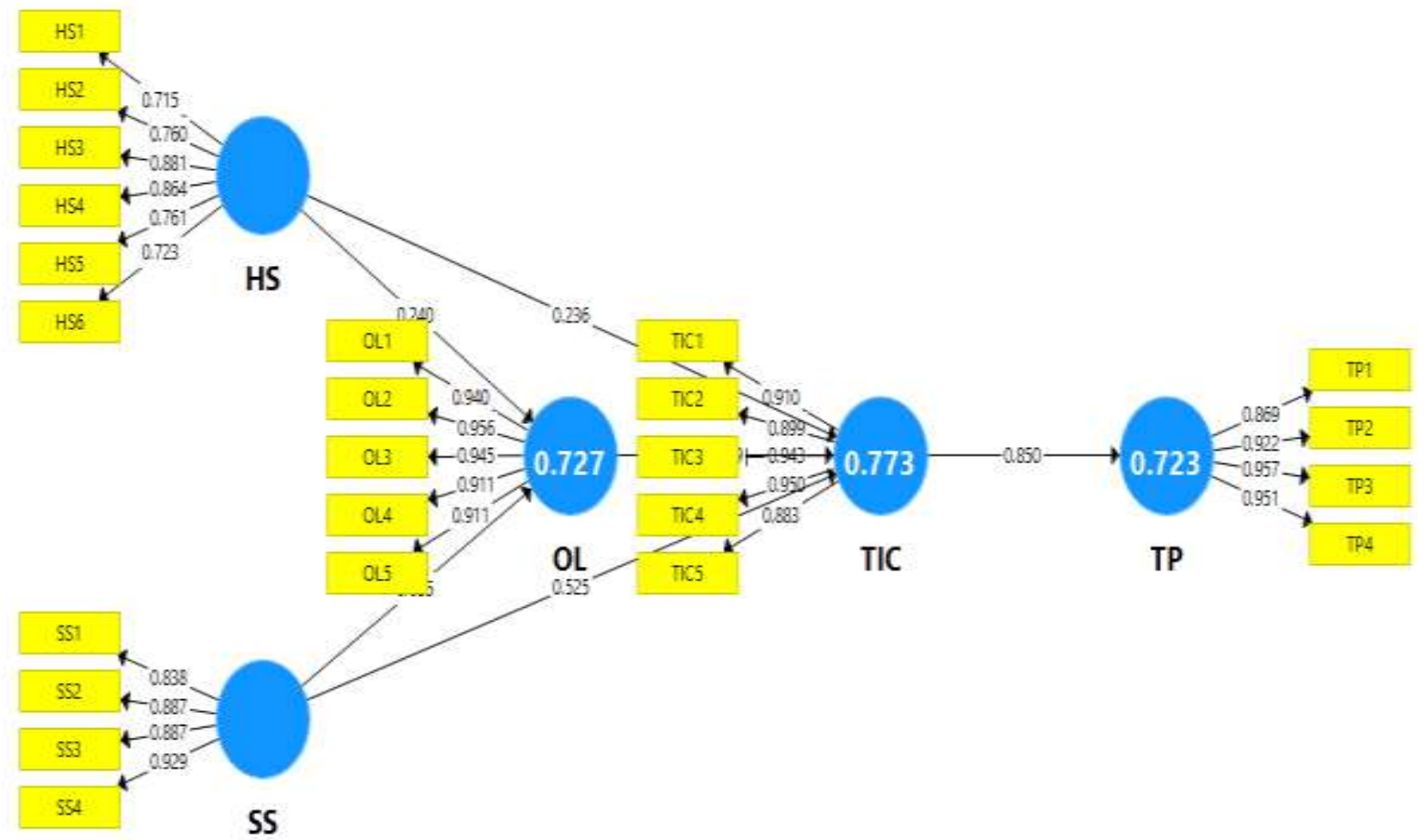

Figure 2. Estimation valid model

All indicators have a loading factor value above 0.5 so that the model meets the convergent validity requirements, that is based on the estimation results of the PLS model in the picture above. Convergent validity is assessed from the AVE value in each construct, besides that it is also seen from the value of the loading factor on each indicator. AVE value for each construct of this research is above 0.5. So the convergent validity of this research model meets the requirements. In table 2 below can see the loading value, cronbach's alpha, composite reliability and AVE of each construct:

Table 2. Items, Loadings, Cronbach's Alpha, Composite Reliability, and Average Variance Extracted (AVE)

\begin{tabular}{cccccc}
\hline Variables & Items & Loadings & $\begin{array}{c}\text { Cronbach's } \\
\text { Alpha }\end{array}$ & $\begin{array}{c}\text { Composite } \\
\text { Reliability }\end{array}$ & AVE \\
\hline Hard Skills & HS1 & 0.715 & 0.876 & 0.906 & 0.619 \\
(HS) & HS2 & 0.760 & & & \\
& HS3 & 0.881 & & & \\
& HS4 & 0.864 & & & \\
& HS5 & 0.761 & & & \\
& HS6 & 0.723 & & & \\
\end{tabular}




\begin{tabular}{|c|c|c|c|c|c|}
\hline $\begin{array}{l}\text { Soft Skills } \\
\quad(S S)\end{array}$ & $\begin{array}{l}\text { SS1 } \\
\text { SS2 } \\
\text { SS3 } \\
\text { SS4 }\end{array}$ & $\begin{array}{l}0.838 \\
0.887 \\
0.887 \\
0.929\end{array}$ & 0.908 & 0.936 & 0.784 \\
\hline $\begin{array}{c}\text { Organizational Learning } \\
(\mathrm{OL})\end{array}$ & $\begin{array}{l}\text { OL1 } \\
\text { OL2 } \\
\text { OL3 } \\
\text { OL4 } \\
\text { OL5 }\end{array}$ & $\begin{array}{l}0.940 \\
0.956 \\
0.945 \\
0.911 \\
0.911\end{array}$ & 0.963 & 0.971 & 0.870 \\
\hline $\begin{array}{c}\text { Teachers' Innovation } \\
\text { Capability } \\
\text { (TIC) }\end{array}$ & $\begin{array}{l}\text { TIC1 } \\
\text { TIC } 2 \\
\text { TIC } 3 \\
\text { TIC } 4 \\
\text { TIC } 5 \\
\end{array}$ & $\begin{array}{c}0.910 \\
0.899 \\
0.943 \\
0.950 \\
0.883 \\
\end{array}$ & 0.953 & 0.964 & 0.842 \\
\hline $\begin{array}{c}\text { Teachers' Performance } \\
\text { (TP) }\end{array}$ & $\begin{array}{l}\text { TP1 } \\
\text { TP2 } \\
\text { TP3 } \\
\text { TP4 }\end{array}$ & $\begin{array}{l}0.869 \\
0.922 \\
0.957 \\
0.951 \\
\end{array}$ & 0.944 & 0.960 & 0.857 \\
\hline
\end{tabular}

\section{Discriminant Validity Test}

To ensure that each concept of each latent variable is different from other latent variables do discriminant validity. If the AVE squared value of each exogenous construct (diagonal value) exceeds the correlation between construct and other construct (values below the diagonal) it can be interpreted that the model has good discriminant validity (Ghozali, 2014). AVE squared value is used as a result of discriminant validity test by looking at the Fornell-Larcker Criterion Value obtained as follows:

Table 3. Discriminant Validity

\begin{tabular}{cccccc}
\hline Variables & $\boldsymbol{H S}$ & OL & SS & TIC & TP \\
\hline HS & $\mathbf{0 . 7 8 7}$ & & & & \\
OL & 0.741 & $\mathbf{0 . 9 3 3}$ & $\mathbf{0 . 8 8 6}$ & $\mathbf{0 . 9 1 7}$ & $\mathbf{0 . 9 2 6}$ \\
SS & 0.764 & 0.839 & 0.856 & 0.850 & \\
TIC & 0.770 & 0.794 & 0.819 & & \\
TP & 0.776 & 0.789 & & \\
\hline
\end{tabular}

The results of the discriminant validity test in table 3 above can conclude that the model meets the discriminant validity show by all constructs have AVE square root values above the correlation value with other latent constructs (through the Fornell-Larcker criteria).

\section{Construct Reliability Test}

The value of Cronbach's alpha and composite reliability of each construct can assess construct reliability. The recommended composite reliability and Cronbach's alpha values are more than 0.7. (Ghozali, 2014). All constructs have composite reliability and Cronbach's alpha value greater than 0.7 (> 0.7$)$ is indicated by the reliability test results in table 2 above. In conclusion, the required reliability have been met all constructs.

\section{Hypothesis Test}

The inner model test was called hypothesis test in PLS. A test of the significance of direct and indirect effects and measurement of the magnitude of the effect of exogenous variables on endogenous variables is included this test. A direct effect test is taken to determine the effect of tacit and hard skills sharing on the organizational learning and teachers' innovation capability. The t-statistic test in the partial least squared (PLS) analysis model using the help of SmartPLS 3.0 software perform using the direct effect test. The table below obtain the bootstrapping technique, R Square values and significance test values: 
Table 4. $R$ Square Value

\begin{tabular}{ccc}
\hline & R Square & R Square Adjusted \\
\hline OL & 0.727 & 0.725 \\
TIC & 0.773 & 0.770 \\
TP & 0.723 & 0.722 \\
\hline
\end{tabular}

Table 5. Hypothesis Test

\begin{tabular}{clccrrc}
\hline Hypothesis & Relationship & Beta & \multicolumn{1}{c}{ SE } & T Statistics & P-Values & Decision \\
\hline H1 & HS -> TIC & 0.236 & 0.071 & 3.316 & 0.028 & Supported \\
H2 & SS -> TIC & 0.525 & 0.071 & 7.413 & 0.000 & Supported \\
H3 & HS -> OL & 0.240 & 0.065 & 3.670 & 0.000 & Supported \\
H4 & SS -> OL & 0.655 & 0.053 & 12.420 & 0.000 & Supported \\
H5 & OL -> TIC & 0.179 & 0.082 & 2.200 & 0.028 & Supported \\
H6 & TIC -> TP & 0.850 & 0.020 & 41.840 & 0.000 & Supported \\
H7 & HS -> OL -> TIC & 0.203 & 0.028 & 3.637 & 0.000 & Supported \\
H8 & SS -> OL -> TIC & 0.118 & 0.050 & 2.341 & 0.020 & Supported \\
& & & & & & \\
\hline
\end{tabular}

According to Table 4 above, hard skills (HS) and soft skills (SS) variables by $72.7 \%$ can explain R Square OL value of 0.727 means that the organizational learning (OL) variables, while other variables explaine the remaining 27.3\% (not discussed in this research). Meanwhile, the value of R Square teachers' innovation capability (TIC) is 0.773 which means that the teachers' innovation capability variable is able to explain the variables of hard skills, soft skills and the organizational learning by $77.3 \%$, while other variables explaine the remaining $22.7 \%$ (not discussed in the research). The $\mathrm{R}$ Square TP value of 0.723 which means that the teachers' performance variable (TP) can be explained by the teachers' innovation capability (TIC) variable by $72.3 \%$, while other variables explaine the remaining $27.7 \%$ (not discussed in this research). While Table 5 displays the effect between the research variables that have been mentioned are showed the T Statistics and PValues .

\section{Discussion}

Based on the results of the research, hard skills sharing has a positive and significant impact on teachers' innovation capability can conclude, both directly and through the organizational learning mediation. This means that the more positive hard skills possessed by teachers, the teachers' innovation capability of individual teachers in school education institutions will also increase. This finding is in line with previous research on business the organizations, namely Perez-Luno et al (2018), Terhorst et al (2018), Boadu et al (2018), Che et al (2019). Likewise, soft skills have a positive and significant effect on teachers' innovation capability, both directly and through the organizational learning mediation. This means that the more positive soft skills possessed by the teacher, the teachers' innovation capability of the individual teacher will also increase. That is, the organizational learning becomes between teachers' soft skills and teachers' innovation capability. 
The results of this research hard skills and soft skills had a positive and significant effect on the organizational learning were conclude. This means that the better hard skills and soft skills controlled by a teacher, the more positive formation and development of the organizational learning in school education institutions. This is in line with the conclusions of Qi \& Chau (2018) research on business the organizations. This implies that teachers who can create new ideas and innovations are the rarest and most valuable resources in the digital age are not ordinary teachers and mediocre $(\mathrm{Xu}$, David \& Kim, 2018). Teachers play a key role in producing and reusing their knowledge and intellectual property through education and teaching (Al-Kurdi, El-Haddadeh \& Eldabi, 2018). For this reason, the scarcity of teachers who have adequate hard skills and soft skills can paralyze the power of innovation, competitiveness, growth and flexibility of school education institutions. No doubt, in the future, the talent and response of school teachers in improving hard skills and soft skills will be an important factor in the future of nation's education. School teachers with skills and innovations will become capital luxury items and instruments of civilization.

Several researches have concluded that soft skills have more effect on innovation than hard skills (Ibrahim, Boerhannoeddin \& Bakare, 2017; Albandea \& Giret, 2018; Viviers, Fouche \& Reitsma, 2016; Escrig-Tena et al, 2018). However, this research shows that hard skills have a greater effect on teachers' innovation capability. The rational possibility is because the research respondents were in big cities, namely in Jakarta, Bogor, Depok, Tangerang and Bekasi (Greater Jakarta).

Based on the findings of this research, the facts conclude that the organizational learning has a positive and significant effect on teachers' innovation capability. The organizational learning also mediates the effect of hard skills and soft skills on teachers' innovation capability. Likewise teachers' innovation capability has a positive and significant effect on teachers' performance. This is consistent with the conclusion of MartinezCosta (2018). The research also concluded that school education institutions could manage past experiences to be combined with the current hard skills and soft skills that teachers have. In essence, positive conditions in the process of knowledge creation in the current education 4.0 eras is able to provided the organizational learning.

\section{Conclusions}

\section{CONCLUSIONS AND SUGGESTIONS}

To add the role of soft skills as a predictor of teachers' innovation capability, schools need to provide autonomy and breadth to share knowledge to the teachers. Therefore, an organizational learning as positive environment that drives the competence and engagement of individual teachers in school education institutions is created by schools. If the performance of each teacher is in good condition knowledge management will run effectively in school education institutions (Manaf et al, 2017).

Knowledge as an important school resource is learned by researchers. Both hard skills and soft skills, can significantly improve school performance can say skills. Individual knowledge into school knowledge is transformed by the organizational learning. The organizational learning acts as a catalyst of the process of knowledge creation among teachers in schools is concluded by this research. Because, in fact, the teacher who carries the obligation to prepare their students to learn and work in this knowledge society.

\section{Managerial Implications}

Based on the conclusions of this research, maximum involvement of all teachers to continuously improve their hard skills and soft skills was billed by the management of school education institutions. The key performance an indicator of each teacher was tailored by teacher training in each section of the school is a necessity with the level of intensity, content and context. In essence, team learning behavior created in the school environment will be a driving force for teachers' innovation (Widmann \& Mulder, 2018).

The process of improving skills to build teachers' innovation capability of school education institutions should not only limit to the internal processes of the school. However, the process of building this innovation through efforts to absorb, articulate, utilize and manage knowledge sourced from external school partners such as parents, government, communities, and other educational institutions are expanded by school management. School management can activate learning from others when assigning their teachers to attend training, seminars, workshops, visits to other schools, meet with school committees and other strategic partners. Because external knowledge, such as those from trainers, coaches, students' parents, the government, the community, and other educational institutions support the teachers' innovation capability of school education institutions. 
In addition, things that need to be considered are commitment to learning and seriousness to be involved in managing the learning environment. The learning process is enjoyed by all members of school education institutions because school education institutions can become learning organizations. School culture that encourages innovation is used as a learning process (Asbari, Santoso \& Purwanto, 2019). Trust, open communication, high involvement, the presence of industry challenges, and a creative work atmosphere are key factors of the organizational learning. Facilitate the fulfillment of these key factors is the task of school management.

\section{Limitation}

Some limitations are owned by this research. First, the effect of hard skills and soft skills on teachers innovation ability, both directly and indirectly through the organizational learning variables analyzed by this research. Searching, exploring and analyzing it are suggested by the author because there may be several other variables that affect the ability of teacher innovation. Second, the environment of the school educational institution is the place where this research was conducted and may not be generalized to other industries. Therefore recommended on this topic in other industries can carry out strongly research.

\section{VI.REFERENCES}

[1] Albandea, I. and Giret, J. (2018), "The effect of soft skills on French post-secondary graduates' earnings", International Journal of Manpower, Vol. 39 No. 6, pp. 782-799. https://doi.org/10.1108/IJM-01-2017-0014

[2] Al-Kurdi, O., El-Haddadeh, R., \& Eldabi, T. (2018). Knowledge sharing in higher education institutions: a systematic review. Journal of Enterprise Information Management, 31(2), 226-246. doi:10.1108/jeim-09-2017-0129

[3] Asbari, M., Santoso, P., \& Purwanto, A. (2019). Influence of Leadership, Motivation, Competence, Commitment and Culture on ISO 9001:2015 Performance in Packaging Industry, Scholars Journal of Economics, Business and Management, 6(12): 577-582.

[4] Asbari, M., Santoso, P., and Purwanto, A. (2019). Influence of Leadership, Motivation, Competence, Commitment and Culture on ISO 9001:2015 Performance in Packaging Industry, Scholars Journal of Economics, Business and Management, 6(12): 577-582. DOI: 10.36347/sjebm.2019.v06i12.005

[5] Asbari, M., Santoso, P., and Purwanto, A. (2019). Pengaruh kepemimpinan dan budaya sekolah terhadap perilaku kerja inovatif pada industri 4.0. JIM UPB (Jurnal Ilmiah Manajemen Universitas Putera Batam), 8(1), 7-15. doi:10.33884/jimupb.v8i1.1562

[6] Asbari, M., Wijayanti, L.M., Hyun, C.C., Purwanto, A., Santoso, P.B., Bernarto, I., Pramono, R., Fayzhall, M. (2020). The Role of Knowledge Transfer and Organizational Learning toBuild Innovation Capability: Evidence from Indonesian Automotive Industry. International Journal of Control and Automation.13(1).19-322

[7] Asbari, M., Wijayanti,L.Hyun,C.C, Purwanto,A, Santoso,P.B.(2020). How to Build Innovation Capability in the RAC Industry to Face Industrial Revolution 4.0?, International Journal of Psychosocial Rehabilitation. 24(6). 2008-2027. DOI: 10.37200/IJPR/V24I6/PR260192

[8] Asher, D., \& Popper, M. (2019). Soft skills as a multilayer phenomenon: the "onion" model. The Learning Organization. doi:10.1108/tlo-06-2018-0105

[9] Assyne N. (2019) Hard Competencies Satisfaction Levels for Software Engineers: A Unified Framework. In: Hyrynsalmi S., Suoranta M., Nguyen-Duc A., Tyrväinen P., Abrahamsson P. (eds) Software Business. ICSOB 2019. Lecture Notes in Business Information Processing, vol 370. Springer, Cham. https://doi.org/10.1007/978-3-030-33742-1_27

[10] Attia, A. and Salama, I. (2018), "Knowledge management capability and supply chain management practices in the Saudi food industry", Business Process Management Journal, Vol. 24 No. 2, pp. 459-477. https://doi.org/10.1108/BPMJ-01-2017-0001

[11] Aulawi, H. (2018). Improving Teacher innovation capability Trough Creativity and Knowledge Sharing Behavior. IOP Conference Series: Materials Science and Engineering, 434, 012242. doi:10.1088/1757-899x/434/1/012242

[12] Azim, S., Gale, A., Lawlor-Wright, T., Kirkham, R., Khan, A., \& Alam, M. (2010). The importance of soft skills in complex projects. International Journal of Managing Projects in Business, 3(3), 387-401. doi:10.1108/17538371011056048

[13] Baldé, M., Ferreira, A. and Maynard, T. (2018), "SECI driven creativity: the role of team trust and intrinsic motivation", Journal of Knowledge Management, Vol. 22 No. 8, pp. 1688-1711. https://doi.org/10.1108/JKM-06-2017-0241

[14] Bani-Melhem, S., Zeffane, R. and Albaity, M. (2018), "Determinants of employees' innovative behavior", International Journal of Contemporary Hospitality Management, Vol. 30 No. 3, pp. 1601-1620. https://doi.org/10.1108/IJCHM-02-2017-0079 
[15] Bashir, M. and Farooq, R. (2019), "The synergetic effect of knowledge management and business model innovation on firm competence: A systematic review", International Journal of Innovation Science, Vol. 11 No. 3, pp. 362-387. https://doi.org/10.1108/JJIS-10-2018-0103

[16] Boadu, F., Xie, Y., Du, Y.-F., \& Dwomo-Fokuo, E. (2018). MNEs Subsidiary Training and Development and Firm Innovative Performance: The Moderating Effects of Tacit and Hard skills Received from Headquarters. Sustainability, 10(11), 4208. doi:10.3390/su10114208

[17] Borges, R., Bernardi, M. and Petrin, R. (2019), "Cross-country findings on soft skills sharing: evidence from the Brazilian and Indonesian IT workers", Journal of Knowledge Management, Vol. 23 No. 4, pp. 742-762. https://doi.org/10.1108/JKM-04-2018-0234

[18] Borrego, G., Morán, A. L., Palacio, R. R., Vizcaíno, A., \& García, F. O. (2019). Towards a reduction in architectural knowledge vaporization during agile global software development. Information and Software Technology. doi:10.1016/j.infsof.2019.04.008

[19] Boske, C. and Osanloo, A. (2015), "Conclusion - Preparing all School Community Leaders to Live their Work", Living the Work: Promoting Social Justice and Equity Work in Schools around the World (Advances in Educational Administration, Vol. 23), Emerald Group Publishing Limited, pp. 405-426. https://doi.org/10.1108/S1479-366020140000023032

[20] Cairó Battistutti, O. \& Bork, D. Cogn Process (2017) 18: 461. https://doi.org/10.1007/s10339-017-0825-6

[21] Campbell, J. (1990), "Modeling the performance prediction problem in industrial and organizational psychology”, in Dunnette, M. and Hough, L. (Eds.), Handbook of Organizational and Industrial Psychology, Consulting Psychologists Press, Palo Alto, CA, pp. 687-732.

[22] Campbell, J.P., McCloy, R.A., Oppler, S.H. and Sager, C.E. (1993), “A theory of performance”, in Schmitt, N. and Borman, W. (Eds.), Personnel Selection in Organizations, Jossey-Bass, San Francisco, CA, pp. 35-70.

[23] Cantwell, J. and Zaman, S. (2018), "Connecting local and global technological knowledge sourcing", Competitiveness Review, Vol. 28 No. 3, pp. 277-294. https://doi.org/10.1108/CR-08-2017-0044

[24] Castela, B., Ferreira, F., Ferreira, J. and Marques, C. (2018), "Assessing the teacher innovation capability of small- and medium-sized enterprises using a non-parametric and integrative approach", Management Decision, Vol. 56 No. 6, pp. 1365-1383. https://doi.org/10.1108/MD-02-2017-0156

[25] Chang, C. and Lin, T. (2015), "The role of organizational culture in the knowledge management process", Journal of Knowledge Management, Vol. 19 No. 3, pp. 433-455. https://doi.org/10.1108/JKM-08-2014-0353

[26] Chang, W.-J., Liao, S.-H., \& Wu, T.-T. (2017). Relationships among organizational culture, knowledge sharing, and innovation capability: a case of the automobile industry in Taiwan. Knowledge Management Research \& Practice, 15(3), 471-490. doi:10.1057/s41275-016-0042-6

[27] Chatterjee, A., Pereira, A. and Sarkar, B. (2018), "Learning transfer system inventory (LTSI) and knowledge creation in organizations", The Learning Organization, Vol. 25 No. 5, pp. 305-319. https://doi.org/10.1108/TLO-06-2016-0039

[28] Che, T., Wu, Z., Wang, Y. and Yang, R. (2019), "Impacts of knowledge sourcing on employee innovation: the moderating effect of information transparency", Journal of Knowledge Management, Vol. 23 No. 2, pp. 221-239. https://doi.org/10.1108/JKM-11-20170554

[29] Che, T., Wu, Z., Wang, Y., \& Yang, R. (2018). Impacts of knowledge sourcing on employee innovation: the moderating effect of information transparency. Journal of Knowledge Management. doi:10.1108/jkm-11-2017-0554

[30] Chen, H., Baptista Nunes, M., Ragsdell, G., \& An, X. (2018). Extrinsic and intrinsic motivation for experience grounded soft skills sharing in Chinese software organisations. Journal of Knowledge Management, 22(2), 478-498. doi:10.1108/jkm-03-2017-0101

[31] Chin, WW. (1998). The Partial Least Squares Approach to Structural Equation Modeling. Modern Methods for Business Research, In: G. A. Marcoulides, Ed., Lawrence Erlbaum Associates Publisher, New Jersey, pp. 295-336.

[32] Cifariello, P., Ferragina, P., \& Ponza, M. (2019). Wiser: A semantic approach for expert finding in academia based on entity linking. Information Systems, 82, 1-16. doi:10.1016/j.is.2018.12.003

[33] Culot, G., Orzes, G., \& Sartor, M. (2019). Integration and scale in the context of Industry 4.0: the evolving shapes of manufacturing value chains. IEEE Engineering Management Review, 1-1. doi:10.1109/emr.2019.2900652

[34] Darwish, T. K., Zeng, J., Rezaei Zadeh, M., \& Haak-Saheem, W. (2018). Organizational learning of Absorptive Capacity and Innovation: Does Leadership Matter? European Management Review. doi:10.1111/emre.12320

[35] Deranek, K., McLeod, A., \& Schmidt, E. (2017). ERP Simulation Effects on Knowledge and Attitudes of Experienced Users. Journal of Computer Information Systems, 1-11. doi:10.1080/08874417.2017.1373610

[36] DOI: http://doi.org/10.36347/sjebm.2019.v06i12.005

[37] Durana, Kral, Stehel, Lazaroiu, \& Sroka. (2019). Quality Culture of Manufacturing Enterprises: A Possible Way to Adaptation to Industry 4.0. Social Sciences, 8(4), 124. doi:10.3390/socsci8040124 
[38] Escrig-Tena, A. B., Segarra-Ciprés, M., García-Juan, B., \& Beltrán-Martín, I. (2018). The impact of hard and soft quality management and proactive behaviour in determining innovation performance. International Journal of Production Economics, $200,1-14$. doi:10.1016/j.ijpe.2018.03.011

[39] Fan, C.S., Wei, X., and Zhang, J. (2017). Soft Skills, Hard Skills, and The Black/White Wage Gap. Wiley Online Library. 55(2):10321052. Doi: https://doi.org/10.1111/ecin.12406

[40] Ferraris, A., Santoro, G. and Scuotto, V. (2018), "Dual relational embeddedness and knowledge transfer in European multinational corporations and subsidiaries", Journal of Knowledge Management, Vol. ahead-of-print No. ahead-of-print. https://doi.org/10.1108/JKM-09-2017-0407

[41] Ferreira, J., Mueller, J. and Papa, A. (2018), "Strategic knowledge management: theory, practice and future challenges", Journal of Knowledge Management, Vol. ahead-of-print No. ahead-of-print. https://doi.org/10.1108/JKM-07-2018-0461

[42] Gale, A. J., Duffey, M. A., Park-Gates, S., \& Peek, P. F. (2017). Soft Skills versus Hard Skills: Practitioners'Perspectives on Interior Design Interns. Journal of Interior Design, 42(4), 45-63. doi:10.1111/joid.12105

[43] Ganguly, A., Talukdar, A. and Chatterjee, D. (2019), "Evaluating the role of social capital, soft skills sharing, knowledge quality and reciprocity in determining teacher innovation capability of an organization", Journal of Knowledge Management, Vol. 23 No. 6 , pp. 1105-1135. https://doi.org/10.1108/JKM-03-2018-0190

[44] Ghozali, I. Structural Equation Modeling, Metode Alternatif dengan Partial Least Square (PLS), Edisi 4. Semarang: Badan Penerbit Universitas Diponegoro. 2014.

[45] Grace, P., Mustamu, R. H., Bisnis, P. M., Manajemen, P. S., Petra, U. K., \& Siwalankerto, J. (2016). Pengaruh Employee Engagement terhadap Kinerja Karyawan pada Perusahaan Keluarga Produsen Senapan Angin, 4(2), $101-107$. http://publication.petra.ac.id/index.php/manajemen-bisnis/article/view/4738

[46] Gunasekaran, A., Subramanian, N., \& Ngai, E. (2018). Quality Management in the 21st Century Enterprises: Research pathway towards Industry 4.0. International Journal of Production Economics. doi:10.1016/j.ijpe.2018.09.005

[47] Guo, Y., Jasovska, P., Rammal, H. and Rose, E. (2018), "Global mobility of professionals and the transfer of soft skills in multinational service firms", Journal of Knowledge Management, Vol. ahead-of-print No. ahead-of-print. https://doi.org/10.1108/JKM-09-2017-0399

[48] Haamann, T., \& Basten, D. (2018). The role of information technology in bridging the knowing-doing gap: an exploratory case study on knowledge application. Journal of Knowledge Management. doi:10.1108/jkm-01-2018-0030

[49] Hair, J. F., Black. W. C., Babin. B. J.; and Anderson. R. E. (2010), Multivariate Data Analysis, 7th ed. New Jersey: Pearson Prentice Hall.

[50] Hamada, T. (2019). Determinants of Decision-Makers' Attitudes toward Industry 4.0 Adaptation. Social Sciences, 8(5), 140. doi: $10.3390 /$ socsci8050140

[51] Hartley, J. (2018), "Ten propositions about public leadership", International Journal of Public Leadership, Vol. 14 No. 4 , pp. $202-217$. https://doi.org/10.1108/IJPL-09-2018-0048

[52] Haseeb, M., Hussain, H. I., Ślusarczyk, B., \& Jermsittiparsert, K. (2019). Industry 4.0: A Solution towards Technology Challenges of Sustainable Business Performance. Social Sciences, 8(5), 154. doi:10.3390/socsci8050154

[53] Hodgins, M. and Dadich, A. (2017), "Positive emotion in knowledge creation", Journal of Health Organization and Management, Vol. 31 No. 2, pp. 162-174. https://doi.org/10.1108/JHOM-06-2016-0108

[54] Holford, W.D. (2018). The future of human creative knowledge work within the digital economy. Futures. doi:10.1016/j.futures.2018.10.002

[55] Holste, J. S., \& Fields, D. (2010). Trust and soft skills sharing and use. Journal of Knowledge Management, 14(1), 128-140. doi:10.1108/13673271011015615

[56] Honeycutt, Jerry. (2000). Knowledge Management Strategies: Strategi Manajemen Pengetahuan. Jakarta : PT. Alex Media Komputindo.

[57] Hong, J. (1999). Structuring for organizational learning. The Learning Organization, Vol. 6 No. 4, pp. $173-186$. https://doi.org/10.1108/09696479910280631

[58] Huang, F., Gardner, S. and Moayer, S. (2016), "Towards a framework for strategic knowledge management practice: Integrating soft and hard systems for competitive advantage", VINE Journal of Information and Knowledge Management Systems, Vol. 46 No. 4 , pp. 492-507. https://doi.org/10.1108/VJIKMS-08-2015-0049 
[59] Huesig, S. and Endres, H. (2019), "Exploring the digital innovation process: The role of functionality for the adoption of innovation management software by innovation managers", European Journal of Innovation Management, Vol. 22 No. 2, pp. 302-314. https://doi.org/10.1108/EJIM-02-2018-0051

[60] Hussain, S. T., Lei, S., Akram, T., Haider, M. J., Hussain, S. H., \& Ali, M. (2018). Kurt Lewin's change model: A critical review of the role of leadership and employee involvement in organizational change. Journal of Innovation \& Knowledge, 3(3), $123-127$. doi:10.1016/j.jik.2016.07.002

[61] Hyun,C.C, Wijayanti,L.M., Asbari,M.,Purwanto,A. Santoso,P.B., IGAK Wardani, Bernarto,I., Pramono,R., (2020). Implementation of Contextual Teaching and Learning (CTL) to

[62] Ibrahim, R., Boerhannoeddin, A. and Bakare, K. (2017), "The effect of soft skills and training methodology on employee performance", European Journal of Training and Development, Vol. 41 No. 4, pp. 388-406. https://doi.org/10.1108/EJTD-08-20160066

[63] Improve the Concept and Practice of Love for Faith-Learning Integration, International Journal of Control and Automation.13(1).365383. http://sersc.org/journals/index.php/IJCA/article/view/5737

[64] Imran, M., Ilyas, M., Aslam, U. and Fatima, T. (2018), "Knowledge processes and firm performance: the mediating effect of employee creativity", Journal of Organizational Change Management, Vol. 31 No. 3, pp. 512-531. https://doi.org/10.1108/JOCM-10-2016-0202

[65] Jakhar, S. K., Mangla, S. K., Luthra, S., \& Kusi-Sarpong, S. (2018). When stakeholder pressure drives the circular economy. Management Decision. doi:10.1108/md-09-2018-0990

[66] Jaleel, S. and Verghis, A.M. (2015). Knowledge Creation in Constructivist Learning. Universal Journal of Educational Research 3(1): 8-12. doi: 10.13189/ujer.2015.030102.

[67] Jiménez-Jiménez, D., \& Sanz-Valle, R. (2011). Innovation, organizational learning, and performance. Journal of Business Research, 64(4), 408-417. doi:10.1016/j.jbusres.2010.09.010

[68] Jou, M. Lin, Y. and Wu, D. (2016) Effect of a blended learning environment on student critical thinking and knowledge transformation, Interactive Learning Environments, 24:6, 1131-1147, DOI: 10.1080/10494820.2014.961485

[69] Kasim, A., Ekinci, Y., Altinay, L. and Hussain, K. (2018) Impact of market orientation, organizational learning and market conditions on small and medium-size hospitality enterprises, Journal of Hospitality Marketing \& Management, 27:7, 855-875, DOI: $10.1080 / 19368623.2018 .1438955$

[70] Kawamura, K. (2016), "Kristine Marin Kawamura, PhD interviews Ikujiro Nonaka, PhD", Cross Cultural \& Strategic Management, Vol. 23 No. 4, pp. 613-632. https://doi.org/10.1108/CCSM-06-2014-0056

[71] Kenayathulla, H., Ahmad, N. and Idris, A. (2019), "Gaps between competence and importance of employability skills: evidence from Malaysia", Higher Education Evaluation and Development, Vol. 13 No. 2, pp. 97-112. https://doi.org/10.1108/HEED-08-2019-0039

[72] Khoshsorour, A., Gilaninia, S. 2018. Kuwait Chapter of the Arabian. Journal of Business and Management Review; Kuwait City 7(3): 1-4. doi: 10.12816/0048627

[73] Kim, N. and Shim, C. (2018). Social capital, knowledge sharing and innovation of small- and medium-sized enterprises in a tourism cluster. International Journal of Contemporary Hospitality Management, Vol. 30 No. 6, pp. 2417-2437. https://doi.org/10.1108/JCHM-07-2016-0392

[74] Klaeijsen, A., Vermeulen, M., \& Martens, R. (2017). Teachers' Innovative Behaviour: The Importance of Basic Psychological Need Satisfaction, Intrinsic Motivation, and Occupational Self-Efficacy. Scandinavian Journal of Educational Research, 62(5), 769-782. doi:10.1080/00313831.2017.1306803

[75] Laker, D. R., \& Powell, J. L. (2011). The differences between hard and soft skills and their relative impact on training transfer. Human Resource Development Quarterly, 22(1), 111-122. doi:10.1002/hrdq.20063

[76] Lecat, A., Beausaert, S. \& Raemdonck, I. (2018). On the Relation Between Teachers' (In)formal Learning and Innovative Working Behavior: the Mediating Role of Employability. Vocations and Learning 11, 529-554. doi:10.1007/s12186-018-9199-x

[77] Lee, J.-C., Shiue, Y.-C., \& Chen, C.-Y. (2016). Examining the impacts of organizational culture and top management support of knowledge sharing on the success of software process improvement. Computers in Human Behavior, 54, 462-474. doi:10.1016/j.chb.2015.08.030

[78] Lee, Peter. (2019). Soft skills and University-Industry Technology Transfer. Research Handbook on Intellectual Property and Technology Transfer (2019, Forthcoming); UC Davis Legal Studies Research Paper Forthcoming. doi: http://dx.doi.org/10.2139/ssrn.3417933

[79] Li, M., Liu, H. and Zhou, J. (2018), "G-SECI model-based knowledge creation for CoPS innovation: the role of grey knowledge", Journal of Knowledge Management, Vol. 22 No. 4, pp. 887-911. https://doi.org/10.1108/JKM-10-2016-0458 
[80] Li, Song, Wang, \& Li. (2019). Intellectual Capital, Knowledge Sharing, and Innovation Performance: Evidence from the Chinese Construction Industry. Sustainability, 11(9), 2713. doi:10.3390/su11092713

[81] Liebowitz, J. and Chen, Y. 2001. Developing knowledge-sharing proficiencies. Knowledge Management Review 3(6): 12-15. https://www.researchgate.net/publication/ 285908349_Developing_knowledge-sharing_proficiencies_Building_a_supportive_ culture_for_knowledge-sharing

[82] Lievre, P. and Tang, J. (2015), "SECI and inter-organizational and intercultural knowledge transfer: a case-study of controversies around a project of co-operation between France and China in the health sector", Journal of Knowledge Management, Vol. 19 No. 5 , pp. 1069-1086. https://doi.org/10.1108/JKM-02-2015-0054

[83] Lin, C.-P. (2006). To Share or Not to Share: Modeling Soft skills Sharing, Its Mediators and Antecedents. Journal of Business Ethics, 70(4), 411-428. doi:10.1007/s10551-006-9119-0

[84] Lin, H., Lee, Y. (2017). A Study of The Influence of Organizational learning on Employees' Innovative Behavior and Work Engagement by A Cross-Level Examination. Eurasia Journal of Mathematics, Science and Technology Education, 13(7), 3463-3478. https://doi.org/10.12973/eurasia.2017.00738a

[85] Lombardi, R. (2019). Knowledge transfer and organizational performance and business process: past, present and future researches. Business Process Management Journal, 25(1), 2-9. doi:10.1108/bpmj-02-2019-368

[86] Lund, H. B., \& Karlsen, A. (2019). The importance of vocational education institutions in manufacturing regions: adding content to a broad definition of regional innovation systems. Industry and Innovation, 1-20. doi:10.1080/13662716.2019.1616534

[87] Ma, Q., Mayfield, M. and Mayfield, J. (2018), "Keep them on-board! How organizations can develop employee embeddedness to increase employee retention", Development and Learning in Organizations, Vol. 32 No. 4, pp. 5-9. https://doi.org/10.1108/DLO-112017-0094

[88] Malik, A. (2019). Creating competitive advantage through source basic capital strategic humanity in the industrial age 4.0. International Research Journal of Advanced Engineering and Science 4(1): 209-215. www.irjaes.com/pdf/V4N1Y18IRJAES/IRJAES-V4N1P195Y19.pdf

[89] Manaf, H. A., Armstrong, S. J., Lawton, A., \& Harvey, W. S. (2017). Managerial Soft skills, Individual Performance, and the Moderating Role of Employee Personality. International Journal of Public Administration, 1-13. doi:10.1080/01900692.2017.1386676

[90] Martínez-Costa, M., Jiménez-Jiménez, D., \& Dine Rabeh, H. A. (2018). The effect of organisational learning on interorganisational collaborations in innovation: an empirical study in SMEs. Knowledge Management Research \& Practice, 1-14. doi:10.1080/14778238.2018.1538601

[91] Mohajan, Haradhan (2016): Sharing of Soft skills in Organizations: A Review. Published in: American Journal of Computer Science and Engineering, Vol. 3, No. 2 (1 July 2016): pp. 6-19. https://mpra.ub.uni-muenchen.de/id/eprint/82958

[92] Moustaghfir, K. and Schiuma, G. (2013), "Knowledge, learning, and innovation: research and perspectives", Journal of Knowledge Management, Vol. 17 No. 4, pp. 495-510. https://doi.org/10.1108/JKM-04-2013-0141

[93] Muhammad, A., Ariyani, E.D., Sadikin, S., Sujana, D. (2019). Factor Analysis of the Companies Demands to the Polytechnic Graduates in Indonesia. Advanced Science Letters, Volume 25, Number 1, January 2019, pp. 117-121(5) DOI: https://doi.org/10.1166/asl.2019.13199

[94] Muñoz, C.A., Mosey, S. and Binks, M. (2015) The tacit mystery: reconciling different approaches to soft skills. Knowledge Management Research \& Practice, 13:3, 289-298, DOI: 10.1057/kmrp.2013.50

[95] Muqowim (2012). Pengembangan Soft Skills Guru. Yogyakarta: Pedagogia

[96] Muscio, A., \& Ciffolilli, A. (2019). What drives the capacity to integrate Industry 4.0 technologies? Evidence from European R\&D projects. Economics of Innovation and New Technology, 1-15. doi:10.1080/10438599.2019.1597413

[97] Muthuveloo, R., Shanmugam, N., \& Teoh, A. P. (2017). The impact of soft skills management on organizational performance: Evidence from Malaysia. Asia Pacific Management Review, 22(4), 192-201. doi:10.1016/j.apmrv.2017.07.010

[98] Naqshbandi, M., Tabche, I. and Choudhary, N. (2019), Managing open innovation: The roles of empowering leadership and employee involvement climate, Management Decision, Vol. 57 No. 3, pp. 703-723. https://doi.org/10.1108/MD-07-2017-0660

[99] Nonaka I., Hirose Nishihara A. (2018) Introduction to the Concepts and Frameworks of Knowledge-Creating Theory. In: Hirose Nishihara A., Matsunaga M., Nonaka I., Yokomichi K. (eds) Knowledge Creation in Community Development. Palgrave Macmillan, Cham. https://doi.org/10.1007/978-3-319-57481-3_1

[100]Nonaka I., Toyama R. (2015) The Knowledge-creating Theory Revisited: Knowledge Creation as a Synthesizing Process. In: Edwards J.S. (eds) The Essentials of Knowledge Management. OR Essentials Series. Palgrave Macmillan, London. https://doi.org/10.1057/9781137552105_4 
[101]Norwich, B., Koutsouris, G., Fujita, T., Ralph, T., Adlam, A. and Milton, F. (2016), "Exploring knowledge bridging and translation in lesson study using an inter-professional team", International Journal for Lesson and Learning Studies, Vol. 5 No. 3, pp. 180-195. https://doi.org/10.1108/JLLS-02-2016-0006

[102]Nouri, B.A., \& Ghorbani, R. (2017). The Effect of Knowledge Management on Organizational Innovation with the Mediating Role of Organizational Learning (Case Study : Agricultural Bank in Iran). Journal of Applied Economics and Business Research JAEBR, 7(3): 194-211. https://www.semanticscholar.org/paper/The-Effect-of-Knowledge-Management-on-Innovation-of-NouriGhorbani/fb9eb1df37e4a47c9b3ac2bbf0bbc4f4907b80a2

[103]Nugroho, M. (2018), "The effects of collaborative cultures and knowledge sharing on organizational learning", Journal of Organizational Change Management, Vol. 31 No. 5, pp. 1138-1152. https://doi.org/10.1108/JOCM-10-2017-0385

[104] Okuyama, R. (2017), "Importance of soft skills in incremental innovation: Implications from drug discovery cases", Journal of Strategy and Management, Vol. 10 No. 1, pp. 118-130. https://doi.org/10.1108/JSMA-02-2016-0016

[105]Parida, V., Sjödin, D., \& Reim, W. (2019). Reviewing Literature on Digitalization, Business Model Innovation, and Sustainable Industry: Past Achievements and Future Promises. Sustainability, 11(2), 391. doi:10.3390/su11020391

[106]Pérez-Fuillerat, N., Solano-Ruiz, M. C., \& Amezcua, M. (2018). Conocimiento tácito: características en la práctica enfermera. Gaceta Sanitaria. doi:10.1016/j.gaceta.2017.11.002

[107]Pérez-Luño, A., Alegre, J., \& Valle-Cabrera, R. (2018). The role of soft skills in connecting knowledge exchange and combination with innovation. Technology Analysis \& Strategic Management, 1-13. doi:10.1080/09537325.2018.1492712

[108]Pérez-Luño, A., Alegre, J., \& Valle-Cabrera, R. (2018). The role of soft skills in connecting knowledge exchange and combination with innovation. Technology Analysis \& Strategic Management, 1-13. doi:10.1080/09537325.2018.1492712

[109]Polanyi, M. (1966). The Tacit dimension. New York: Doubleday \& Co.

[110]Prameswari, M., Asbari, M., Purwanto, A., Ong, F., Kusumaningsih, S.W., Mustikasiwi, A., Chidir, G., Winanti, Sopa, A. (2020). The Impacts of Leadership and Organizational Culture on Performance in Indonesian Public Health: The Mediating Effects of Innovative Work Behavior. International Journal of Control and Automation, 13(02), $216-227$. Retrieved from http://sersc.org/journals/index.php/IJCA/article/view/7630

[111]Prasarnphanich, P., Janz, B. and Patel, J. (2016), "Towards a better understanding of system analysts' soft skills: A mixed method approach", Information Technology \& People, Vol. 29 No. 1, pp. 69-98. https://doi.org/10.1108/ITP-06-2014-0123

[112]Purwanto, A., Wijayanti, L.M., Hyun, C.C., Asbari, M. (2020). The Effects of Transformational, Transactional, authentic, Authoritarian Leadership style Toward Lecture Performance of Private University in Tangerang. Dinasti International Journal of Digital Business Management (DIJDBM), 1(1), 29-42. DOI:https://doi.org/10.31933/dijdbm.v1i1.88

[113]Qi, C. and Chau, P.Y.K. (2018) Will enterprise social networking systems promote knowledge management and organizational learning? An empirical study, Journal of Organizational Computing and Electronic Commerce, 28:1, 31-57, DOI: $10.1080 / 10919392.2018 .1407081$

[114]Rainsbury, E., Hodges, D., Burchell, N. \& Lay, M. C. (2002). Ranking workplace competencies: Student and graduate perceptions. Asia-Pacific Journal of Cooperative Education, 3(2), 8-18. https://hdl.handle.net/10289/3219

[115]Razmerita L., Phillips-Wren G., Jain L.C. (2016) Advances in Knowledge Management: An Overview. In: Razmerita L., PhillipsWren G., Jain L. (eds) Innovations in Knowledge Management. Intelligent Systems Reference Library, vol 95. Springer, Berlin, Heidelberg. https://doi.org/10.1007/978-3-662-47827-1_1

[116]Rothberg, H. and Erickson, G. (2017), "Big data systems: knowledge transfer or intelligence insights?", Journal of Knowledge Management, Vol. 21 No. 1, pp. 92-112. https://doi.org/10.1108/JKM-07-2015-0300

[117]Ruiz-Torres, A., Cardoza, G., Kuula, M., Oliver, Y. and Rosa-Polanco, H. (2018), "Logistic services in the Caribbean region: An analysis of collaboration, innovation capabilities and process improvement", Academia Revista Latinoamericana de Administración, Vol. 31 No. 3, pp. 534-552. https://doi.org/10.1108/ARLA-03-2017-0078

[118]Rumanti, A. A., Samadhi, T. M. A. A., Wiratmadja, I. I., \& Sunaryo, I. (2018). A systematic literature review on knowledge sharing for innovation: Empirical study approach. 5th International Conference on Industrial Engineering and Applications (ICIEA). doi:10.1109/iea.2018.8387153

[119]Rumanti, A. A., Wiratmadja, I. I., Sunaryo, I., Ajidarma, P., \& Ari Samadhi, T. M. A. (2019). Firm Teacher innovation capability through Knowledge Sharing at Indonesian Small and Medium Industries: Impact of Tacit and Hard skills Perspective. 2019 IEEE 6th International Conference on Industrial Engineering and Applications (ICIEA). doi:10.1109/iea.2019.8714947

[120]Samsir, S. (2018), The effect of leadership orientation on innovation and its relationship with competitive advantages of small and medium enterprises in Indonesia, International Journal of Law and Management, Vol. 60 No. 2, pp. 530-542. https://doi.org/10.1108/IJLMA-01-2017-0005 
[121]Santoro, G., Vrontis, D., Thrassou, A., \& Dezi, L. (2017). The Internet of Things: Building a knowledge management system for open innovation and knowledge management capacity. Technological Forecasting and Social Change. doi:10.1016/j.techfore.2017.02.034

[122] Sasaki, Y. (2017), "A note on systems intelligence in knowledge management", The Learning Organization, Vol. 24 No. 4, pp. 236244. https://doi.org/10.1108/TLO-09-2016-0062

[123] Schuckert, M., Kim, T., Paek, S. and Lee, G. (2018), "Motivate to innovate: How authentic and transformational leaders influence employees' psychological capital and service innovation behavior", International Journal of Contemporary Hospitality Management, Vol. 30 No. 2, pp. 776-796. https://doi.org/10.1108/IJCHM-05-2016-0282

[124]Serna M., E., Bachiller S., O., \& Serna A., A. (2017). Knowledge meaning and management in requirements engineering. International Journal of Information Management, 37(3), 155-161. doi:10.1016/j.ijinfomgt.2017.01.005

[125] Sopa, A., Asbari, M., Purwanto, A., Santoso, P.B., Mustofa, Hutagalung, D., Maesaroh, S., Ramdan, M., Primahendra, R. (2020). Hard Skills versus Soft Skills: Which are More Important for Indonesian Employees Innovation Capability. International Journal of Control and Automation, 13(02), 156 - 175. Retrieved from http://sersc.org/journals/index.php/IJCA/article/view/7626

[126] Sousa, M. J., \& Rocha, Á. (2019). Strategic Knowledge Management in the Digital Age. Journal of Business Research, 94, $223-226$. doi:10.1016/j.jbusres.2018.10.016

[127]Spraggon, M. and Bodolica, V. (2017), "Collective soft skills generation through play: Integrating socially distributed cognition and transactive memory systems", Management Decision, Vol. 55 No. 1, pp. 119-135. https://doi.org/10.1108/MD-05-2015-0173

[128] Stachová, K., Papula, J., Stacho, Z., \& Kohnová, L. (2019). External Partnerships in Employee Education and Development as the Key to Facing Industry 4.0 Challenges. Sustainability, 11(2), 345. doi:10.3390/su11020345

[129] Stanica, S. and Peydro, J. (2016), "How does the employee cross-training lean tool affect the knowledge transfer in product development processes?", VINE Journal of Information and Knowledge Management Systems, Vol. 46 No. 3, pp. 371-385. https://doi.org/10.1108/VJIKMS-11-2015-0061

[130]Starbuck, W. (2017), "Organizational learning and unlearning", The Learning Organization, Vol. 24 No. 1, pp. $30-38$. https://doi.org/10.1108/TLO-11-2016-0073

[131] Stewart, C., Schiavon, L.M. and Bellotto, M.L. (2017) Knowledge, nutrition and coaching pedagogy: a perspective from female Brazilian Olympic gymnasts, Sport, Education and Society, 22(4): 511-527, DOI: 10.1080/13573322.2015.1046428

[132] Swierczek, A. (2019), "Manufacturer structural embeddedness and the network rent: the intervening role of relational embeddedness in the triadic supply chains", Supply Chain Management, Vol. 24 No. 3, pp. 334-354. https://doi.org/10.1108/SCM-06-2018-0232

[133] Tang, V., Yanine, F. and Valenzuela, L. (2016), "Data, information, knowledge and intelligence: The mega-nano hypothesis and its implications in innovation", International Journal of Innovation Science, Vol. 8 No. 3, pp. 199-216. https://doi.org/10.1108/IJIS-072016-0022

[134]Terhorst, A., Lusher, D., Bolton, D., Elsum, I., \& Wang, P. (2018). Soft skills Sharing in Open Innovation Projects. Project Management Journal, 49(4), 5-19. doi:10.1177/8756972818781628

[135] Torres, O. J. J., \& Liang, D. (2016). Knowledge Sharing and the Teacher innovation capability of Chinese Firms: The Role of Guanxi. 2016 International Conference on Industrial Engineering, Management Science and Application (ICIMSA). doi:10.1109/icimsa.2016.7504015

[136] Tsai, F. and Hsu, I. (2019), "The effects of social capital on knowledge heterogeneity", Management Decision, Vol. 57 No. 5, pp. 1237-1253. https://doi.org/10.1108/MD-12-2016-0909

[137] Tsotsotso, K., Montshiwa, E., Tirivanhu, P., Fish, T., Sibiya, S., Mlangeni, T., Moloi, M. and Mahlangu, N. (2017), "Determinants of skills demand in a state- intervening labour market: The case of South African transport sector", Higher Education, Skills and WorkBased Learning, Vol. 7 No. 4, pp. 408-422. https://doi.org/10.1108/HESWBL-08-2017-0050

[138]Urban, B. and Gaffurini, E. (2018), "Social enterprises and organizational learning in South Africa", Journal of Entrepreneurship in Emerging Economies, Vol. 10 No. 1, pp. 117-133. https://doi.org/10.1108/JEEE-02-2017-0010

[139] Vijande M.L.S., Sánchez J.Á.L. (2017) The Effects of Organizational learning on Innovation and Performance in Kibs: An Empirical Examination. In: Campbell C.L. (eds) The Customer is NOT Always Right? Marketing Orientationsin a Dynamic Business World. Developments in Marketing Science: Proceedings of the Academy of Marketing Science. Springer, Cham. https://doi.org/10.1007/9783-319-50008-9_227

[140] Villaluz, V. and Hechanova, M. (2019), "Ownership and leadership in building an innovation culture", Leadership \& Organization Development Journal, Vol. 40 No. 2, pp. 138-150. https://doi.org/10.1108/LODJ-05-2018-0184

[141] Viviers, H., Fouché, J. and Reitsma, G. (2016), "Developing soft skills (also known as pervasive skills): Usefulness of an educational game", Meditari Accountancy Research, Vol. 24 No. 3, pp. 368-389. https://doi.org/10.1108/MEDAR-07-2015-0045 
[142]Wang, C., Chen, M. and Chang, C. (2019), "The double-edged effect of knowledge search on innovation generations", European Journal of Innovation Management, Vol. ahead-of-print No. ahead-of-print. https://doi.org/10.1108/EJIM-04-2018-0072

[143]Wang, J., \& Liu, L. (2019). Study on the mechanism of customers' participation in knowledge sharing. Expert Systems, e12367. doi:10.1111/exsy.12367

[144] Wang, X., Arnett, D. and Hou, L. (2016), "Using external knowledge to improve organizational innovativeness: understanding the knowledge leveraging process", Journal of Business \& Industrial Marketing, Vol. 31 No. 2, pp. 164-173. https://doi.org/10.1108/JBIM-04-2014-0064

[145]Wang, Z., \& Wang, N. (2012). Knowledge sharing, innovation and firm performance. Expert Systems with Applications, 39(10), 8899-8908. doi:10.1016/j.eswa.2012.02.017

[146] Wetzel R., Tint B. (2019) Using Applied Improvisation for Organizational learning in the Red Cross Red Crescent Climate Centre. In: Antonacopoulou E., Taylor S. (eds) Sensuous Learning for Practical Judgment in Professional Practice. Palgrave Studies in Business, Arts and Humanities. Palgrave Macmillan, Cham. https://doi.org/10.1007/978-3-319-99049-1_3

[147] Widmann, A. and Mulder, R. (2018), "Team learning behaviours and innovative work behaviour in work teams", European Journal of Innovation Management, Vol. 21 No. 3, pp. 501-520. https://doi.org/10.1108/EJIM-12-2017-0194

[148] Widoyoko, E.P. (2009). Evaluasi Program Pembelajaran Panduan Praktis bagi Pendidik dan Calon Pendidik (Yogyakarta: Pustaka

[149] Wójcik, M., Jeziorska-Biel, P., \& Czapiewski, K. (2019). Between words: A generational discussion about farming knowledge sources. Journal of Rural Studies, 67, 130-141. doi:10.1016/j.jrurstud.2019.02.024

[150]Xu, M., David, J. M., \& Kim, S. H. (2018). The Fourth Industrial Revolution: Opportunities and Challenges. International Journal of Financial Research, 9(2), 90. doi:10.5430/ijfr.v9n2p90

[151] Yang, Z., Nguyen, V. and Le, P. (2018), Knowledge sharing serves as a mediator between collaborative culture and teacher innovation capability: an empirical research, Journal of Business \& Industrial Marketing, Vol. 33 No. 7, pp. 958-969. https://doi.org/10.1108/JBIM-10-2017-0245

[152]Zambon, I., Cecchini, M., Egidi, G., Saporito, M. G., \& Colantoni, A. (2019). Revolution 4.0: Industry vs. Agriculture in a Future Development for SMEs. Processes, 7(1), 36. doi:10.3390/pr7010036

[153]Zebal, M., Ferdous, A., \& Chambers, C. (2019). An integrated model of marketing knowledge - a soft skills perspective. Journal of Research in Marketing and Entrepreneurship. doi:10.1108/jrme-03-2018-0018

[154]Zhang, C., Xiao, H., Gursoy, D. and Rao, Y. (2015). Soft skills spillover and sustainability in destination development. Journal of Sustainable Tourism. 23(7): 1029-1048, DOI: 10.1080/09669582.2015.1032299

[155]Zhu, Q., Krikke, H. and Caniëls, M. (2018), Supply chain integration: value creation through managing inter-organizational learning. International Journal of Operations \& Production Management. 38(1): 211-229. https://doi.org/10.1108/IJOPM-06-2015-0372

[156]Zouaghi, F., Sánchez, M., \& Martínez, M. G. (2018). Did the global financial crisis impact firms' innovation performance? The role of internal and external knowledge capabilities in high and low tech industries. Technological Forecasting and Social Change. 132: 92104. doi:10.1016/j.techfore.2018.01.011

[157] Campbell, J. (1990), "Modeling the performance prediction problem in industrial and organizational psychology", in Dunnette, M. and Hough, L. (Eds.), Handbook of Organizational and Industrial Psychology, Consulting Psychologists Press, Palo Alto, CA, pp. 687-732.

[158]Campbell, J.P., McCloy, R.A., Oppler, S.H. and Sager, C.E. (1993), “A theory of performance”, in Schmitt, N. and Borman, W. (Eds.), Personnel Selection in Organizations, Jossey-Bass, San Francisco, CA, pp. 35-70. 